\title{
Research on Equity Incentive of Listed Companies

\author{
${ }^{1}$ School of Management, Yulin University, China,719000 \\ a245445986@qq.com
} \\ Linli Bian", a *
}

\begin{abstract}
Keywords: Listed company; Equity incentive; Countermeasure analysis
\end{abstract}
\begin{abstract}
From early 1990s joint-stock company in the process of ESOP, to the end of twentieth Century and early twenty-first Century the management equity incentive, and then since 2002 the emergence of MBO, to improve equity incentive now and in-depth stage, equity incentive in our country has developed a long history. But because of the lack of relevant policies, the environment is not perfect, resulting in the incentive effect is not very ideal. This paper mainly studies the current situation of equity incentive, existence question and optimized strategy.
\end{abstract}

\section{Introduction}

Since 2006 the implementation of "measures on the administration of equity incentive of listed companies", China's enterprises have implemented, from 2006 to 2012, has been more than 400 state-owned and private listed companies in the implementation of equity incentive policy, with the separation of ownership and management, the use of equity incentive policy will be long-term interests and the interests of shareholders, managers of the company the interests are closely linked, so as to prevent the ills of operators only pay attention to the company's short-term interests of the listed companies in China, more and more attention in the aspect of incentive equity incentive is a long-term incentive system, and this system will be more and more companies and company executives performance together.

\section{Development Status of Equity Incentive System}

The use of equity incentive system in the western developed countries has experienced decades of development, has played an important role in enhancing corporate value and promoting national economic growth, the United States is known as the "engine" of the new economy. In recent years, the equity incentive system has become the focus of scholars in our country and enterprises has been discussed, China attaches great importance to the government and enterprises.

Since 2005, the number of Listed Companies in China have implemented the equity incentive policy showed substantial growth, especially the management was promulgated, many listed companies in the implementation of the system cleared the obstacle, and provide policy guidance, so that we realize the feasibility of equity incentive system. By the end of March 2012, China's total more than 400 listed companies in the implementation of equity incentive policy. Due to our policies to further improve and perfect, further analysis of the governance structure of listed companies to adjust the equity incentive to the implementation of the background environment has been greatly improved, equity incentives have become increasingly standardized, the equity incentive of state owned enterprises from the state-owned holding listed companies kicked off. But the present situation of our country's development leads us to the implementation of the system, there are still some problems, so we have to ask for the The problems are discussed in depth and the problems are solved at the same time.

In recent years, China's listed companies to use the equity incentive policy of enterprises increased year by year, the equity incentive as a good incentive means, is also gradually recognized by more people. We do some research on the equity incentive policy used in our country:Sample Firms distributed in 10 industries, the number and proportion of forestry and animal husbandry sideline are: $1(2.5 \%), 3(7.5 \%)$ mining industry, manufacturing $10(25 \%)$, coal gas industry $2(5 \%)$, $3(7.5 \%)$ construction industry, information technology industry $3(7.5 \% 3)$, wholesale and retail 
trade $(7.5 \%), 5(12.5 \%)$ financial industry, real estate industry, $5(12.5 \%)$, other $5(12.5 \%)$. 1 in the enterprise scale, the number of Sample Firms and the proportion of distribution are: 600 million yuan and below 3 (7.5\%), $6 \sim 1$ billion 200 million 3 yuan (7.5\%), $12 \sim 2$ billion 100 million yuan 6 (15\%), $21 \sim 3$ billion 300 million yuan 8 (20\%), 33 - 10 billion yuan 10 (25\%), 10 billion yuan more than $10(25 \%)$.

The majority of people tend to implement the equity incentive system (accounting for $75 \%$ of the share), but $60 \%$ of them believe that there are some problems in the stock incentive system, which need to be improved.

\section{The Problems of Stock Right Incentive System}

The Governance Structure of Listed Companies is Irrational. The listed company of our country has formed by the general meeting of shareholders, board of directors, board of supervisors and the internal governance structure decision management mechanism. However, the listed companies in China within the lack of internal supervision mechanism effectively. The real control of listed companies is the company's operation and management personnel, the weakening of the supervision of the responsibility of the operator and the formation of "internal control". If the management of the lack of necessary supervision and restraint, will lead to unfair transactions between the company shareholders. This is not conducive to the development of the company, but also damaged the company's image and interests, at the same time, the principal-agent relation of moral risk. But the current insider listed companies control phenomenon is serious, leads to the insider trading behavior between listed companies and a large number of short-term interests of controlling shareholders. To strengthen corporate governance. The perfection of the structure is the most basic condition for the effectiveness of the equity incentive, otherwise, the equity incentive will become a tool for the collusion and corruption of the minority listed company's decision-makers.

Have not yet Established Effective Tax Policies and Accounting Standards. At present, our country's tax on stock option has been relaxed, but shares the tax burden is still very heavy, increase the incentive cost, reduce the real income of managers, is not conducive to the implementation of equity incentive plan of.2006 in February, the Ministry of Finance issued the "accounting standards for Enterprises No. eleventh shares to pay", and formally the implementation in January 1, 2007. It provides a legal basis for our country's special accounting process of executive stock options. But the code is mainly for the central enterprises, and the index set of equity incentive is seldom considered, and granted to the company's relevant listed company stock option information, performance evaluation on operator performance information disclosure do not the specific requirements and regulations.

The Assessment Index System is not Perfect. The implementation of an important condition of equity incentive is the enterprise performance evaluation system has been set up, and our country's existing performance evaluation system is the evaluation object and target fuzzy, single index, standard single defects, the financial index system is relatively comprehensive enough, not detailed enough, and non financial indicators less involved, not comprehensive and objectively reflect the efforts of enterprises operating performance and management, to a certain extent weakens the effectiveness of equity incentive. At present in our country, with the majority of listed companies performance evaluation standard is the rate of return on net assets and net profit growth rate, performance evaluation standards tend to the financial index system relatively speaking is not comprehensive, not detailed enough, and non financial indicators less involved, a serious blow to the enthusiasm of employees, intensified the internal contradictions, at the same time, the lack of a reasonable performance The efficiency evaluation standard is easy to appear unfair phenomenon between listed companies, so that the incentive effect of stock option drops, and it is difficult for enterprises to achieve the expected effect. 


\section{The Optimization Measures of Listed Company Equity Incentive}

To Improve the Corporate Governance Structure. In order to avoid the "internal control", improve the system of independent directors, the company can introduce external directors, establish a board of directors as the core of corporate governance. The shareholder structure must be diversified, in order to avoid such equity incentive policy has become a small number of staff pocketed tools. Secondly, improve the governance structure of listed companies need to construct the supervision effective restraint mechanism in listed companies, in addition to independent directors, the remuneration committee can be built to contain the relationship between stakeholders, transparent bottom increase the decision and fair degree. At the same time, the government can set up supervising institutions related, to support and guide.

Strengthen the Construction of Manager Market and Capital Market. The perfect manager market is an important condition of equity incentive means can be implemented effectively. Therefore, our country should speed up the training of occupation managers of the talent market should be established to operate ability as the standard managers market, avoid the board power, encourage talented managers. Occupation talent shows itself according to the requirement of market economy, take fairness and justice. The competition principle, one can for the whole society to open recruitment, on the other hand from the Higher Institute of scientific research institutions with high-quality training and selection of promising young scholars entry, can gradually improve. Talent is the subject of listed enterprise value creation, and is the main object of equity incentive policy incentives.

Make More Reasonable and Comprehensive Performance Evaluation Index. The equity incentive system, there should be an objective and scientific performance evaluation system, otherwise, it will make the operator or the original shareholders interests. Therefore, the listed company should be established by the company's profitability, financial structure, ability and growth ability to match the business performance evaluation system. The key of equity incentive in listed companies can be summarized as the game relationship between managers and shareholders, therefore, listed the company should handle the responsibility, right, profit relationship between the three, make a feasible evaluation system, neither the standard setting is too high, not up to the incentive effect, not the standard setting is too low, so will cause the market to question the company, unfavorable to the long-term development of the company. The listed companies should set up comprehensive evaluation index system. Focus on financial indicators and non-financial indicators can not be ignored, to study abroad, The introduction of EVA, the Balanced Scorecard and other advanced way of assessment management. Such assessment results can be more comprehensive, more fair and reasonable to reflect it, and strive to enterprise performance incentive pay after each match, the perfect show, so as to ensure the effective implementation of equity incentive effect. In short, the establishment of a set of the scientific, reasonable, fully reflect the operator's effort and management effect evaluation index, comprehensive evaluation of enterprise future development potential, for the implementation of equity incentive mechanism is very important.

Improve Relevant Laws and Regulations. In order to solve the listed company equity incentive problems, effectively alleviate the lack of understanding of the equity incentive of listed companies, improve the relevant laws and regulations is the key to solve misunderstanding. On the one hand, the state has promulgated the supervision on the implementation of the implementation of regulations and policies, in order to strengthen the supervision of listed companies, with heavy penalties for violation of the relevant provisions the behavior, strengthen law enforcement, in order to reduce the "covert operation" speculation; on the other hand, to improve the relevant laws and regulations, the introduction of the current policies and regulations, still have to be improved and added where hope relevant institutions can replenish this, China should fully learn from international experience, the existing improvements were adjusted in order to ensure the fairness and justice. The incentive process successively from the company law, securities law, tax law and relevant accounting standards and other aspects, many Perspective, the practice of eliminating the obstacle of law system for equity incentive of listed companies. 
In summary, the equity incentive in our country at present is touted, many listed companies have already implemented or prepared to implement the equity incentive system, and the formation of a variety of modes. However, the implementation of environmental conditions and the surrounding this system of our country are still in the initial stage, a lot of system and environment to be improved, but we have reason some believe that the equity incentive system will be respected in the future, a good management talent can create great wealth for the company. A huge pay traditional currency, inevitably can only play a short-term incentive effect, and can not play a long-term incentive effect. And the company paid too much money, will also bring heavy the burden to the company's cash flow. Therefore, it is a reasonable and effective incentive methods, warmly welcome to the company's top managers and shareholders of the ideal incentive mode in the near future. Here, we believe that there will be more companies to join the tide, more and more enterprises to benefit.

\section{References}

[1] Zhang Xin, Tube xueyang problem of equity incentive of listed companies [J]. financial market research. ,2011(10)

[2] Wang Yukun. The analysis of existing problems and Countermeasures of enterprise [J]. technology and the development of equity incentive of listed companies, 2009. (10)

[3] Shi Jin Xin. The equity incentive of Listed Companies in China[J].Economist, 2017 (3)

[4] Wang Yahui. used in the listed company and the financial control of [J].The equity incentive $2016(10)$

[5] Wei Min. Discussion on equity incentive system of Listed Companies in China [J]. Contemporary economy, 2014 (5) 